УДК 130.2+78.01(477)

\title{
A. Скорик
}

\section{НАСИЛЛЯ І СУБ'СКТ В СУЧАСНІЙ АУДІОВІЗУАЛЬНІЙ КУЛЬТУРІ}

Використовування «театру жорстокості» у візуальних сучасних мистецтвах, зокрема, на телебаченні - це трансгресивний жест, намагання стерти межі між мистецтвом та життям, вихід поза межі людського завдяки інтроверсії, особливого погляду всередину себе, щоб знайти там свою справжню сутність. Образи катастрофічних видовищ, руїн та ін. діють як спосіб репрезентувати знайоме незнайоме, як один з найбільш ефективних візуальних засобів включення пам'яті як мнемотичного знаку. В мотиві руїни відомі елементи реального ніби стираються, прогалини в цих стертих місиях стимулюють механізми відтворення образу в уяві, які тісно пов'язані з функціонуванням процесу отримання насолоди від образу, від його впізнавання в незнайомому.

Ключові слова: ідея, жорстокість, інтроверсї̈, викривленість, метод, реальність, візуалізація, функціонування.

Перебуваючи в рамках людського соціуму, насилля успішно зайняло свою нішу в мас-медійному контенті. Особливо «виграшно» його розміщення виглядає в аудіовізуальній продукції. I не лише завдяки насиченості «картинки» екрану, а й завдяки потужності цієї форми людської діяльності. На жаль, катарсиси жертвоприношення не стали громадським набутком. Це данина стародавнім варіантам міфологізації насилля. Однак супроти міфологічному характеру жорстокої «натуралізації агресивності і насильства» сучасність характеризується специфічно людськими проявами жорстокості. Е. Фромм назвав цю ситуацію «людськими пристрастями» [16, с. 23], що властиві такій соціальній детермінанті людського буття, як насилля.

Багатовекторність форм насилля зумовила багатовекторність теоретичних підходів до його осмислення. Певну класифікацію насильства пропонує російський вчений Г. І. Козирєв: за формами насильницької взаємодії, заподіюваного збитку, за суб'єктами конфліктної ситуації.

Науковці визначають культурне насилля як аспект культури, що може використовуватися для легалізації насилля в його прямій i структурній формі.

Генеза проблематики насильства чітко відслідковується в аудіовізуальному напрямку сучасного медійного контенту. Історична скла-

(C) Скорик А., 2014 
дова сучасного соціуму, на жаль, беззаперечно надала константне значення відомому висловлюванню Геракліта: «війна - [polemos] батько всіх, цар усіх: одних вона називає богами, інших - людьми, одних створює рабами, інших - вільними» [15, с. 202]. А за Арістотелем, «насилля це примус, а таким назвається те, що заважає й перешкоджає в будь-чому, всупереч бажанню необхідності; тому воно й найтяще» [3, с. 151]. Політичні традиції, зокрема, сприяють переходу монополізації насилля до рівня влади і права. Сучасна теорія насилля закцентувалася в царині політичної філософії. Світ наче охопила суцільна суспільна домовленість. Т. Гоббс розмірковує про неможливість мирного людського співіснування в силу існування самої природи ворогування одного з одним. Ця сутністність людини закладена самою природою на генетичному, інстинктивному рівні. Така ідея існування людини є ії природним правом, стверджував Д. Локк у «Двох трактатах про правління» [9, с. 263-270].

Автор «Суспільного договору» Ж.-Ж. Руссо теоретизовано обгрунтував цивільне суспільство, закцентувавшись на юридичні права особи [13, с. 85-98].

Вироблені в історії основи юридичного підгрунтя осуду насилля покладені і сьогодні в основу засад конституційного права багатьох суспільних угруповань. I лише I. Кантом була проголошена закономірність вічності миру і створення на його засадах союзницьких стосунків між людьми та державами. Тут «навіть найменша держава могла б очікувати своєї безпеки й права не від своїх власних сил, а винятково від такого великого союзу народів» [6, с. 285].

Дисонанс звучання ще одного мислителя, власне, урівнює чашу терезів світових постулатів на цю тему. Г. Гегель писав: «Війна зберігає здорову моральність народів у їх індиференції стосовно визначеностей щодо їхньої звичності й укорінення, подібно до того, як рух вітру охороняє озера від гниття, що загрожує їм при тривалому затишку, так само як народам - тривалий, або, тим більше, вічний мир» [5, c. 289].

Ж. Сорель в «Міркуваннях про насилля» представляє пролетарське насилля: гуманізм та доброта є заохоченням хитрощів, що панують в ринкових відносинах соціуму.

Сучасність, відображена в мас-медіа і на відео, - це сучасне суспільство, що виокремлює свою сутність насильства. Здавалося б непорушні, насправді традиції трансформуються: змінюється тип злочинців і тип їхніх злочинів. Виникає «екранізація» художніх, пуб- 
ліцистичних, документальних творів з чітким засиллям насильства, втіленого у яскравих творчих образах. «Інтелектуальність» такого розгульництва ще не була відомою історії мас-медійності, але вже зазнала свого розгулу у війнах, терактах, соціальних «майданах». Сумний висновок французького історика Ф. Фюре: «Якщо скласти загальний список знаменитих авторів, які в різний час були комуністами або співчували комунізму, були фашистами або співчували фашизму, то ми отримаємо теперішній Готський альманах інтелектуальної, наукової та літературної еліти» [14, с. 20].

Повсякденність життя не варто списувати на незадоволення культурою. Сучасність наче сотворила межі насилля і його Героя. Його місце більш значуще, аніж місце самого творця життєвих благ. Представники Франкфуртської школи зробили величезний внесок для розвінчування насильницької ідеології. Серед них вже відомі Т. Адорно і його «Дослідження авторитарної особистості» [1], «Одномірна людина» Г. Маркузе [10], «Анатомія деструктивності» Е. Фрома [16].

Так чи інакше, у них звучить схильність до пошуку психологічних детермінант, закладених в основу насильства. Стереотипи цинізму, інстинктивність імпульсів щодо зовнішнього світу, надмірне зацікавлення ексцесами... Це ознаки постмодерністського суспільства, що оповите оманами свого насилля. Насилля присутнє у репресіях, класових й етнічних чистках, депортаціях... Постмодернізм засуджує прояви нетерпимості, репресивності: стратегія майстерного викриття різного роду насилля залишається привілейованою дійсністю сучасності.

На рухливість сучасного суспільства звертає увагу і англійський культуролог Скотт Леш у роботі «Критика інформації» («Critique of information», 2002). Він вважає, що таке суспільство будується не в межах соціокультурного процесу, що зв’язує минуле і майбутнє, а навколо комунікацій, що мають тільки теперішнє. Як наслідок з'являється не виробництво символів, а їх постійний рух. Саме ця зміна, на думку С. Леша, формує одну з найбільш принципових відмінностей інформаційного суспільства від усіх попередніх. Причину цьому англійський культуролог бачить у трансформаційних процесах суспільства, рух яких відбувається в бік відриву від його об'єктивної основи, переносення людей до сфери суб'єктивного. Саме це й призводить до перетворення життя на гру - «як єдину недиференційовану реальність». Як неоднаразово натякає С. Леш, «критика інформації знаходиться у самій інформації» [17, с. 9]; «інформаційна критика повинна бути критикою позатрансцендентною» $[17$, с. 9]. 
П. Віріліо зазначає, що під час глобалізаційних процесів поняття територіального «сусідства» (contigui'te) націй застаріває і йому на зміну приходить неподільність (continuite) того, що ми бачимо і чуємо, а політичні кордони реального геополітичного простору перетворюються в хроно-політичні поділи реального часу передачі образу і звуку. Французький мислитель розрізнює два взаємодоповнюючих аспекти глобалізації. Перший - максимальне скорочення відстаней в результаті стискання часу переміщень і передач на відстань. Другий - розвиток загального телеспостереження. Саме завдяки «трансгорізонту бачення», що дозволяє бачити те, що раніше було недоступним, протягом всього часу ми існуємо в постійно «телеприсутньому» світі. Продовжуючи думку Гастона Башляра: «Доля будь-якого образу - його розбухання», П. Віріліо підкреслює, що «ця доля образу здійснюється завдяки науці, перетворюється на оптичну технонауку. В недалекому минулому - за допомогою телескопа і мікроскопа. В недалекому майбутньому - за допомогою домашнього телеспостереження <...> Активна (хвильова) оптика повністю трансформувала використання пасивної (геометричної) оптики часів (...) Галілея. Складається враження, що зникнення лінії географічного обрію неминуче призводить до введення заміщуючого горизонту. «Штучний горизонт» екрана чи монітора свідчить про перевагу медійної перспективи над безпосередньою просторовою перспективою. Об’ємність «телеприсутньої» події стає вагомішою, ніж тривимірні речі і їхнє розташування $<\ldots>$ Врешті-решт, загальна візуалізація є найбільш помітним проявом віртуалізаціі. Горезвісна «віртуальна реальність» складається не стільки з переміщень у кіберпросторі Мережі, скільки у збільшенні оптичних подібностей (копій) реального світу».

Відзначимо, що сучасні методи медіанасилля часто базуються на методах, віднайдених творцем «театру жорстокості» А. Арто. В першу чергу це розуміння життя як нескінченної гри, як візуальної спонтанної практики. В численних зразках продукції кіно- та телемистецтва, комп'ютерних версіях життя постає перед глядачем (або слухачем) як театральна вистава, а театральна вистава як життя, яка, за А. Арто, впливає на фізичному, емоційному, позасвідомому рівнях, а не на рівні інтелектуального сприйняття. Вважаємо, що методи «театру жорстокості» А. Арто в сучасній аудіовізуальній культурі занурюють глядача у візуальне та зачіплюють його несвідомі інстинктивні глибини, щоб реципієнт почав відчувати нестерпність, насиченість, сконцентрованість переживань аж до очищаючого його страждання (майже 
до катарсису, за Арістотелем, що мав відбуватися у давньогрецької трагедіï). Такий вплив є жорстокістю, що очищує.

Крім того, феномен «жорстокості» розрахований на те, що будуть викликані такі почуття, як, наприклад, страх, який, на нашу думку є, з одного боку, культурною травмою, а з іншого - захисною реакцією людини на побачене або почуте. Використовування «театру жорстокості» у візуальних сучасних мистецтвах, зокрема, на телебаченні це трансгресивний жест, намагання стерти межі між мистецтвом та життям, вихід поза межі людського завдяки інтроверсії, особливого погляду всередину себе, щоб знайти там свою справжню сутність. Ідеї, закладені в концепції «театру жорстокості» А. Арто, не вмирають і сьогодні: завдяки медіа людство бачить увесь абсурд, жорстокість, нікчемність сучасного світу - рецепієнт, шляхом заперечення, повертається до справжності, первинного життя, розуміючи при цьому його викривленість. Звичайно, що так відбувається не завжди, проте один із методів 3МІ базується, на наш погляд, саме на системі відомого французького теоретика та митця.

Образи катастрофічних видовищ, руїн та ін. діють як спосіб репрезентувати знайоме незнайоме, як один з найбільш ефективних візуальних засобів включення пам'яті як мнемотичного знаку. В мотиві руїни відомі елементи реального ніби стираються, прогалини в цих стертих місцях стимулюють механізми відтворення образу в уяві, які тісно пов'язані з функціонуванням процесу отримання насолоди від образу, від його впізнавання в незнайомому.

Споглядання образів катастрофи, руйнації реального вводить у стан заціпеніння, яке пов'язане з почуттям порожнечі (відсутність певних елементів у структурі образу, місця розриву, в яких репрезентативна модель викриває свою ефективність), почуттям відсутності смислу, зникнення людини. Якщо художній образ відсилає до ілюзорного, розпадається, то включення механізму пам'яті в створення, завершення візуального образу за допомогою фантазії $є$ так само й ілюзією пам'яті. Образи руїн реальності, образи незавершеної катастрофи, які наша уява і пам'ять допрацьовують, дописують у місцях відсутності, прогалинах цих образів, викривають і механізм роботи нашої свідомості як механізм впорядкування, механізм, який сформований певним набором канонів вже історично сформованої системи візуальної репрезентації.

Своїм першоджерелом, як багатозначне поняття, «насилля» в аудіовізуальних ЗМК завдячує своїм корінням поняттю «культура 
війни». Увібравши в себе увесь суперечливий досвід людства, його перетворювальні уроки вона вже не є однозначно протилежною категорією до «категорії миру». Діалектика суперечливого, перехід однієї якості в іншу, динаміка багатоаспектного - таким є іiі культуролого-концептуальний вимір. Формування поняттєвого апарату специфіки сучасної цивілізації, аналіз світоглядних проблем війни, критичний розгляд iï інтерпретацій... Все це сприяло запровадженню, а згодом і масовому засиллю соціального конфлікту у ЗМК. Метод його розв'язання є суперечливим і складним. Але, якшо вимір «культура війни» формує цінності, як зі знаком «плюс» (героїзм, хоробрість, сміливість, патріотизм), так і зі знком «мінус» (жорстокість), то поняття «насилля» (чи «насилля і суб'єкт») у ЗМК - поняття однозначно «мінусове». Моніторинг ЗМК не приховує зло і загарбництво як акцію. Соцально-психологічні і соціально-етичні аспекти цих односторонніх «мінусів» формують екранного «героя» з природою агресивного відтінку, мілітаристського духу, стереотипів образу ворога. Ці взаємопоштовхи виявляють у кожній категорії головуючі, превалюючі якості. Але відомо, що розбрат завжди пропагує новітню техніку, а освіченість змінювала самі його віяння впливами інтелектуальних обріїв.

Концепції «культури війни» опрацьовані ЮНЕСКО в Декларації про культуру миру, Програмі дій у галузі культури миру. Їхня мета сприяти глобальному рухові на етапі переходу від культури насилля і війни до культури миру. Заклики до ненасилля у третьому тисячолітті здатні формувати цінності миролюбства, миротворчості, толерантності, неагресивності мислення і неагресивності поведінки. Це принципово нове розуміння широти амплітуди миротворчості не лише між державами, але й соціокультурними групами з максимальним врахуванням найперше соціокультурних і національних особливостей.

Осуджування насилля - один із засобів боротьби з ним. Але заслабкий в своєму розвитку. Піратські вибухи і викрадення, присутність терактів означає відсутність ідеологічних постулатів, що втратили будь-яку прогнозованість. А ще - втрата жертовних ознак «подвигів», відмінностей між легітимним і нелегітимним. А їхня сукупність складає систему відмінностей. При втраті ознак жертовності проглядається утруднення із регуляцією насильства, що з'являється як грізна стихія, хаотичне начало. Демократія припускає таке начало початком дисгармонії у людських стосунках. А це вже недооцінювання фактора культурного існування суспільства. Довівши процеси 
уніфікації цього фактора, криза жертовності набуває чималого гігантизму. Така масштабність характерна для глобалізуючого світу. Це і $є$ проблемою людства. Спалах соціальних напруг у своїх першоджерелах функціонує саме там, у цих зруйнованих суспільних структурах соціальної комунікації. Вона може хоч би частково конструювати соціальну напругу. Ця необхідність умови існування здорового суспільства пропагується культурологічними мас-медійними контентами. Недетермінованість - руйнівна, детермінованість - не опирається світовим процесам.

Засновник та ідеолог ОC Linux Лінус Торвальдс стверджує, що «технології не змінюють суспільство - це суспільство змінює технології». Окрім «рогу достатку» комунікаційні технології представили суспільству і негативну сторону свого існування. Ризики соціальних катастроф у своєму розвитку стрімко випереджують соціально-культурний розвиток суспільства, який протягом історичного розвитку людства завжди був механізмом стабільності. Поява насилля в інформаційному середовищі сприяє зацікавленості у дослідженнях шодо зміни структурності насилля в глобалізаційних обставинах. Пріоритетність гуманітарної переваги відведе людство від потурань власноруч. Трансформованість в особистісній свідомості, суспільних її проявах виникає через стрімку тенденцію розвинутості комп'ютерних технологій. А вони, у свою чергу, породжують насилля. Віртуальність просторовості комп’ютеризації успішно здійснюється знаковим заміщенням. Технічність виступає тут незамінним однодумцем. «Віртуальність у квадраті» [7] - відмінність віртуальності сьогоднішнього часу.

Конвергенція урізноманітнення мережі - уніфікований засіб дієвості глобалізаційних процесів. Нівелювання відмінностей створює стандартизованість подання матеріалів. Парадоксальність індивідуалізованості опосередковується міжособистісними зв'язками. Ізольованість стає не тільки парадоксальним, але й стало традиційним чинником людського життя. Відсутність діалогічності, фрагментарність, нециклічність, часом неможливість зорієнтуватися у потоках різноманітної інформації сприяють втратам справжніх і ціннісних орієнтирів життя. Така «скринька Пандори» стає справжньою пасткою. Пошуки пізнавального та інформативного перестають бути стимулом для соціальних дій: самозадоволення собою і довколишнім середовищем є наслідком спостереження. Це призводить до втрати самоідентичності особи та зумисного нав'язування іншою особою 
інформативного потоку. Таке насилля веде до обмеження волевиявлення особи.

Науковцями досліджено класифікацію основних видів насилля: дезінформація, диверсифікація суспільної свідомості, психологічний тиск і пропаганда, розповсюдження чуток [12, с. 32-34]. Поряд із специфічними особливостями - зростанням анонімності насильницьких текстів, маніпулюванням свідомістю - інтернет-ресурс породжує імітування комунікативності своїх основних функцій, породжує нагнітання репресивності, збудження до неадекватних дій. Пошук супротиву, очевидно, неможливо знайти без задіювання людських знань, інтелекту, схильності до аналітики.

Геополітичність взаємин є пошуком нової інформаційної сфери існування. Прагнення людини до комфортності, вигідності коштує дорого. А тому тут можливе застосування певної силової активності. Комунікаційний контент модифікує світові процеси. Зброя по інформованості залишається особливо актуальною, але найважливіше - нічим незамінною. Інформаційний тероризм у розумінні кібертероризму як своєрідний вид насилля особливо загрозливий світові. Шпигунство і хакерство, ризики онлайну, озброєність соціальних «інженерів» стали транснаціональними «коридорами» кібер-злочинців [11, с. 34-52].

Лише національний і світовий рівень тривоги сприятиме створенню системних заходів боротьби з комп'ютерною злочинністю.

Останні роки існує думка, що третя світова війна буде не ядерною, не «холодною», а так би мовити - тролінговою війною. І вона вже, схоже, почалася. Існуючі армії тролів з боку великих держав (Америка, Росія, СС) «б'ються» на інформаційних просторах за людські душі, розум, за думки і почуття. Йдеться вже не просто про «інформаційну травму», яку відчувають практично всі люди через ЗМК - фактично тролінг стає новим, дуже витонченим і жорстоким засобом «насилля суб'єкта», знищення, приниження, зневаги особистості, що, загалом, можливо порівняти із вбивством. Тобто сьогодні можна говорити про певну концепцію тролінгу в Інтернеті, та завдяки тролінгу розповсюдження «викривленої» інформації в мас-медійних комунікаційних системах.

Яскравим прикладом сьогодення (особливо з початку євромайдану в Україні у листопаді 2013 р.) є нарощування великої кількості «тролів» на інтернет-сторінках в соціальних мережах. Це, безперечно - інформаційна війна, яка використовує досить складні 
механізми маніпулювання свідомістю людей на рівні позасвідомості. Серед дієвих масово-інформаційних маніпулятивних прийомів необхідно назвати наклеювання ярликів для дискредитації певних осіб або ідей без будь-яких доказів (наприклад, використання оказіоналізму «нашист», «фашист» та ін. як контекстуального синоніму); уживання концептуальних метафор (зокрема, і політичних), інвектив, трансформація відомих фразеологізмів та утворення перифрази (особливо у заголовках), активне залучення крилатих висловів тощо $[8$, c. $60-66]$.

Є принципові ознаки у поведінці так званих «російських тролів». Серед них можна назвати як найбільш популярні такі: ображати українських громадян, які вийшли на євромайдан або розмовляють українською мовою; дивуватися з приводу незадоволення українських громадян режимом колишнього президента України В. Януковича і називати дезінформацією будь-які негативні дані про нього; налаштовувати жителів Криму на користь ідеї приєднання півострова до Росії або хоча б від'єднання від України.

Безумовно, наведений приклад стосується тролінгу інформаційного простору не лише з точки зору його політизації. Посилення діяльності в інтернет-просторі, «потрапляння в топи» «Живого журналу» і Twitter стає механізмом «накручування» рейтингів багатьох відомих людей і в різних сферах культурного життя. Йде інформаційна війна, в якій вже не існує ніяких приципів моралі, а будь-які засоби стають нормою життя, адже і життя як таке вже саме по собі нічого не значить. Бо, як казав відомий фашистський ідеолог Йозеф Геббельс, «дайте мені засоби масової інформації і я з будь-якого народу зроблю стадо свиней!».

Отже, безумовно, поняття «насилля суб'єкта» є, так чи інакше, пов'язаним із актуальним поняттям «інформаційна травма». Значення виокремлення терміна «інформаційна травма» із загального простору культури з'явилося в силу підвищеної динаміки інформаційного фону життя. Кризова ситуація в перенасиченості інформаційного забезпечення, з одного боку, а з іншого - іiї недостатність призводить до прямого зв'язку травматизму особистості із викривленням (спотворенням) інформації на всіх рівнях мас-медіа.

Поряд з поняттям «інформаційна травма» існує більш глобальне поняття - «культурна травма», яке, на нашу думку, впливає на попереднє. Культурна травма в культурології визначається як процес, що виявляється в колективній свідомості членів спільноти через відчуття 
того, що вони стали мимовільними учасниками «жахливої» події, яка назавжди залишиться в пам'яті цієї групи, безповоротно змінюючи іiї майбутню ідентичність.

Сучасний стан культури, зокрема й української, характеризується соціальними трансформаціями, коли старі значення, цінності, норми життя втрачають свій первинний сенс і починається формування нових. Такий процес має для суспільства, безумовно, стресовий, травматичний характер. Тому поняття «культурна травма» сьогодні являє собою аналітичний інструмент культурологічної науки, що дозволяє ефективно працювати з процесами реальності, впорядковуючи різноманітність смислів і практик, пов'язаних з колективним досвідом переживань і його наслідками.

\section{СПИСОК ЛІТЕРАТУРИ}

1. Адорно Т. Исследования авторитарной личности / Теодор Адорно. М. : Серебряные нити, 2001. - 416 с.

2. Апель К.-О. Дискурс і відповідальність : проблема переходу до постконвенціональної моралі / Карл-Отто Апель ; [пер. $з$ нім. В. Купліна]. К. : Дух і Літера, 2009. - 430 с. - (Сучасна гуманітарна бібліотека)

3. Аристотель. Сочинения : [в 4 томах]. - М. : Мысль, 1975. - Т. 1. $550 \mathrm{c}$.

4. Багдасарьян Н. Г. Виртуальная реальность: попытка типологизации / Н. Г. Багдасарьян, В. Л. Силаева // Философские науки. - 2003. - № 6. C. $39-58$.

5. Гегель Г. В. Философия права / Г. В. Гегель. - М. : Мысль, 1990. - 524 с.

6. Кант И. К вечному миру / И. Кант // Сочинения : [в 6 томах]. - М., 1966. - Т. 6. - С. 257-309.

7. Компьютерная преступность : новые возможности [Электронный ресурc]. - Режим доступа : http://www.cybercrime.report.ru

8. Кудрявцева Л. О. Сучасні аспекти дослідження мас-медійного дискурсу: експресія - вплив - маніпуляція / Л. О. Кудрявцева, Л. П. Дядечко, О. М. Дорофєєва, І. О. Філатенко, Г. А. Черненко // Мовознавство. - 2005. № $1 .-$ С. 58-66.

9. Локк Д. Два трактата о правлении /Д. Локк // Сочинения : [в 3 томах]. - М. : Мысль, 1988. - Т. 3. - С. 263-270.

10. Маркузе Г. Эрос и цивилизация. Одномерный человек : Исследования идеологии развитого индустриального общества / Г. Маркузе. - М. : АСТ, 2003. $-526 \mathrm{c}$.

11. Михайлов В. А. Особенности развития информационно-коммуникативной среды современного общества / В. А. Михайлов, С. В. Михайлов // Актуальные проблемы теории коммуникации : сборник научных трудов. СПб : Изд-во СПб ГУ, 2004. - С. 34-52. 
12. Петрик В. М. Сучасні технології та засоби маніпулювання свідомістю, ведення інформаційних війн і спеціальних інформаційних операцій / В. М. Петрик, О. А. Штоквиш, В. І. Полевий. - К. : Росава, 2006. - 208 с.

13. Руссо Ж.-Ж. Об общевственном договоре. Трактаты / Жан-Жак Руссо. - М. : Канон-Пресс, 2000. - С. 85-98.

14. Сорель Ж. Размышления о насилии / Ж. Сорель. - М. : Польза, 1907. $-225 \mathrm{c}$.

15. Фрагменты ранних греческих философов. - М. : Наука, 1989. - 576 с.

16. Фромм Е. Анатомия человеческой деструктивности / Е. Фромм. M. : ACT, 2006. $-635 \mathrm{c}$.

17. Lash S. Critique of information / S. Lash. - London ; Trousand Oaks (Ca): Sage Publications, 2002. - 234 pp. - P. 220

Скорик А. Насилие и субъект в современной аудиовизуальной культуре. Использование «театра жестокости» в визуальных современных искусствах, в частности, на телевидении - это трансгрессивный жест, попытка стереть границы между искусством и жизнью, выход за пределы человеческого благодаря интроверсии, особого взгляда внутрь себя, чтобы найти там свою настоящую сущность. Образы катастрофических зрелищ, руин и др. действуют как способ представить знакомое незнакомое, как один из наиболее эффективных визуальных средств включения памяти как мнемотичного знака. В мотиве руины известные элементы реального будто стираются, пробелы в этих стертых местах стимулируют механизмы воссоздания образа в воображении, которые тесно связаны с функционированием процесса наслаждения от образа, от его узнавания в незнакомом.

Ключевые слова: идея, жестокость, интроверсии, извращенность, метод, реальность, визуализация, функционирование.

A. Skoryk. Violence and subject in contemporary audiovisual culture. Using the «theater of cruelty» in modern visual arts, particularly on television, as a transgressive gesture, attempts to erase the boundaries between art and life, exit beyond human due to introversion, a special look inside yourself to find where your true essence is. Images of catastrophic sights, ruins, etc. act as a way to represent the familiar unfamiliar, as one of the most effective visual means including memory as mnemonic instrument. In the ruins motive known elements like real erased, erased gaps in these areas stimulate the mechanisms of reproduction of the image in the imagination, which are closely related to the functioning of the process of enjoying the image of its recognition in the strange.

Keywords: idea, cruelty, introversion, indirectivity, method, reality, visualization, operation.

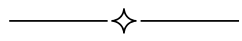

